\title{
Implementasi Algoritma Advanced Encryption Standard (AES) 128 Untuk Enkripsi dan Dekripsi File Dokumen
}

\author{
Asri Prameshwari ${ }^{1}$, Nyoman Putra Sastra ${ }^{2}$ \\ Fakultas Teknik Elektro, Universitas Udayana \\ Jln. Jalan Kampus Bukit Jimbaran 80361 Denpasar Bali, Telp: 0361-703315 \\ e-mail: ${ }^{1}$ asri.prameshwari@yahoo.com, ${ }^{2}$ putra.sastra@unud.ac.id
}

\begin{abstract}
Abstrak
Keamanan data atau informasi adalah hal yang sangat penting bagi pengguna jaringan internet saat ini. Kasus penyadapan akan pesan atau informasi merupakan salah satu hal yang sangat merugikan, dengan adanya kemungkinan terjadinya kejadian ini, maka perlunya peningkatan dalam hal keamanan pertukaran informasi menjadi penting. Pada saat ini, keamanan pertukaran informasi ini perlu mendapatkan perhatian khusus, maka penelitian ini akan membuat suatu implementasi kriptografi algoritma AES-128 untuk enkripsi dan dekripsi data yang berupa file dokumen (PDF, DOC, TXT). Algoritma Advanced Encryption Standard (AES) dipilih karena memiliki suatu tingkat keamanan pertukaran informasi yang cukup bagus, dan pada penelitian ini diuji coba file dokumen untuk melihat kecepatan waktu yang dibutuhkan selama proses enkripsi dan dekripsi.
\end{abstract}

Kata kunci: AES-128, Keamanan, Enkripsi, Dekripsi.

\begin{abstract}
Data information security is important for the internet users lately. Many cases regarding wiretapping message and information is very detrimental, with the possibility of the occurrence of the events, the need for improvement in terms of exchange data information security becomes important. At this time data information security needs to get special attention, this research will make an implementation of cryptographic algorithm AES-128 to encrypt and decrypt data specifically in file document such as pdf, doc and txt. The Algorithm Encryption Standard (AES) was chosen because it has a level of security that is a pretty good in exchange of data information and this study the document files was tested to see the speed of time needed during the encryption and decryption process.
\end{abstract}

Keywords: AES-128, Security, Encryption, Decryption.

\section{Pendahuluan}

Kerahasiaan dari data atau informasi merupakan suatu kelengkapan pelayanan yang dibuat untuk menjaga agar informasi yang tersimpan tidak dapat dibaca atau dibuka oleh pihak yang tidak berhak. Upaya dalam menjaga kerahasiaan dari data informasi tersebut sudah tercetus sejak jaman dahulu tepatnya pada jaman romawi dengan metode pergeseran huruf atau karakter dengan dasar nilai tertentu.

Pada jaman modern berbasis teknologi komputer, upaya-upaya tersebut berkembang dengan menggunakan algoritma yang diciptakan oleh banyak ahli, namun hal tersebut masih saja dapat dipecahkan oleh pihak-pihak yang tidak bertanggung jawab, maka dari itu perkembangan algoritma kriptografi semakin pesat demi keamanan data.

Konsep perlindungan akan data informasi dapat dilakukan dengan sistem enkripsi dan dekripsi menggunakan algoritma yang telah ditetapkan sebelumnya. Proses enkripsi di sini diartikan sebagai proses perubahan dari suatu pesan asli (plain text) menjadi suatu pesan yang terlindungi dalam hal ini pesan yang tersandi (chiper text), sedangkan untuk proses dekripsi adalah suatu proses pengembalian pesan tersandi yang terlindungi menjadi bentuk data asli pesan tersebut [3].

Pada kedua proses tersebut dibutuhkan suatu pengaman yang menjamin bahwa pesan tersebut terlindungi pada prosesnya, pengaman tersebut dinamakan key. Fungsi dari key ini adalah kunci untuk membuka atau mengawali tiap proses, pada penelitian ini key yang digunakan adalah algoritma kunci simetri (Simmetric-key algorithm) yaitu algoritma kunci yang sama pada saat melakukan proses enkripsi dan dekripsi. 
Pada penelitian ini proses enkripsi dan dekripsi yang dilakukan dalam perlindungan data informasi berbasiskan algoritma kriptografi yaitu Algoritma AES-128 dengan Kunci Simetri. Penerapan algoritma ini akan dilakukan pada pengamanan jenis data berjenis dokumen dengan tipe $p d f$, doc, txt. Pada proses pembuatan aplikasi perlindungan enkripsi dekripsi ini akan menggunakan software Microsoft Visual Studio 2012 sebagai bahasa pemrograman.

\section{Tinjauan Pustaka (State of the Art)}

Algoritma Advanced Encryption Standard (AES) adalah suatu algoritma block chiper dan mempunyai sifat simetri yang menggunakan kunci simetri pada waktu proses enkripsi dan dekripsi [2]. Pada tahun 2001, AES digunakan sebagai standar algoritma kriptografi terbaru yang dipublikasikan oleh NIST (National Institute of Standard and Technology) sebagai pengganti algoritma DES (Data Encryption Standard) yang sudah berakhir masa penggunaannya. Algoritma AES adalah algoritma kriptografi yang dapat mengenkripsi dan mendekripsi data dengan panjang kunci yang bervariasi, yaitu 128 bit, 192 bit, dan 256 bit [1]. Perbedaan dari ketiga urutan tersebut adalah panjang kunci yang mempengaruhi jumlah round (perputaran) yang dapat digambarkan dalam bentuk tabel [6]:

Tabel 1. Tabel urutan data algoritma AES.

\begin{tabular}{cccc}
\hline & Panjang Kunci & Panjang Blok & Jumlah Putaran \\
\hline AES-128 & 4 & 4 & 10 \\
\hline AES-129 & 6 & 4 & 12 \\
\hline AES-256 & 8 & 4 & 14 \\
\hline
\end{tabular}

Pada Tabel 1 di atas dijelaskan mengenai tipe dari algoritma AES dengan panjang kunci, panjang blok dan jumlah putaran yang berbeda-beda. Untuk penelitian ini digunakan AES-128 bit dengan jumlah putaran enkripsi sebanyak 10 kali.

Terdapat 4 transformasi putaran pada proses enkripsi dan dekripsi [7]:

1. SubBytes

Berfungsi untuk menukar isi dari byte dengan menggunakan tabel substitusi.

2. ShiftRows

Proses pergeseran blok per baris pada state array.

3. MixColumn

Proses mengalikan blok data (pengacakan) di masing-masing state array dengan rumus sebagai berikut:

4. AddRoundKey

$$
A(x)=\{03\} x^{2}+\{01\} x^{2}+\{01\} x+\{02\}
$$

Mengombinasikan state array dan round key dengan hubungan XOR.

Pada proses dekripsi algoritma AES:

1. InvShiftRows

Melakukan pergeseran bit ke kanan pada setiap blok baris.

2. InvSubBytes

Setiap elemen pada state dipetakan dengan tabel Inverse S-Box.

3. InvMixColumn

Setiap kolom dalam state dikalikan dengan matriks AES.

4. AddRoundKey

Mengombinasikan state array dan round key dengan hubungan XOR.

Penggambaran proses transformasi putaran dapat dilihat dari Gambar 1 [6] :

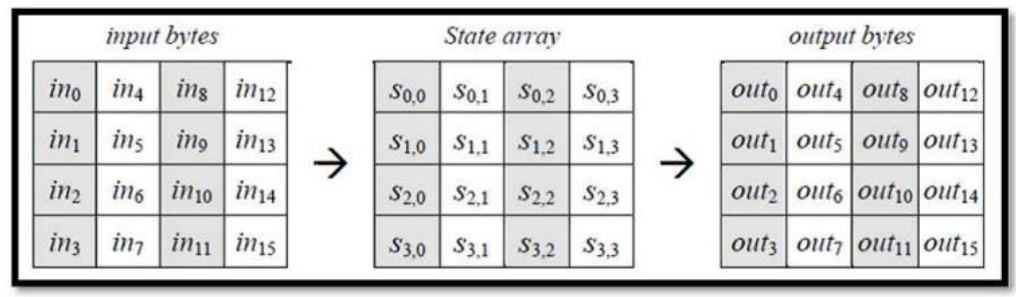

Gambar 1. Proses input bytes, state array, output bytes. 
Dari Gambar 1 dapat dijelaskan bahwa algoritma AES ini ada dasarnya, algoritma AES ini merupakan array of bytes dengan dua dimensi yang disebut dengan state. Rumus ukuran dari state adalah NROWS $x$ NCOLS, dari state ini akan diproses enkripsi dan dekripsi yang hasilnya akan dimasukkan ke dalam array of state. Pada awal proses enkripsi data dimasukkan ke dalam input bytes yang kemudian akan di salin kedalam array state, pada proses ini nantinya akan dilakukan enkripsi dan dekripsi, hasil keluarannya akan ditampung dalam output bytes.

Pada awal proses enkripsi, input yang telah disalin ke dalam state akan mengalami transformasi AddRoundKey. Setelah itu state akan mengalami transformasi SubBytes, ShiftRows, MixColumns, dan AddRoundKey secara berulang-ulang sebanyak round/putaran (Nr). Proses ini dalam algoritma AES disebut sebagai round function. Round yang terakhir, state tidak diberikan transformasi MixColumns [2]. Ilustrasi proses awal enkripsi dengan menggunakan algoritma AES -128 dijelaskan pada Gambar 2 [6]:

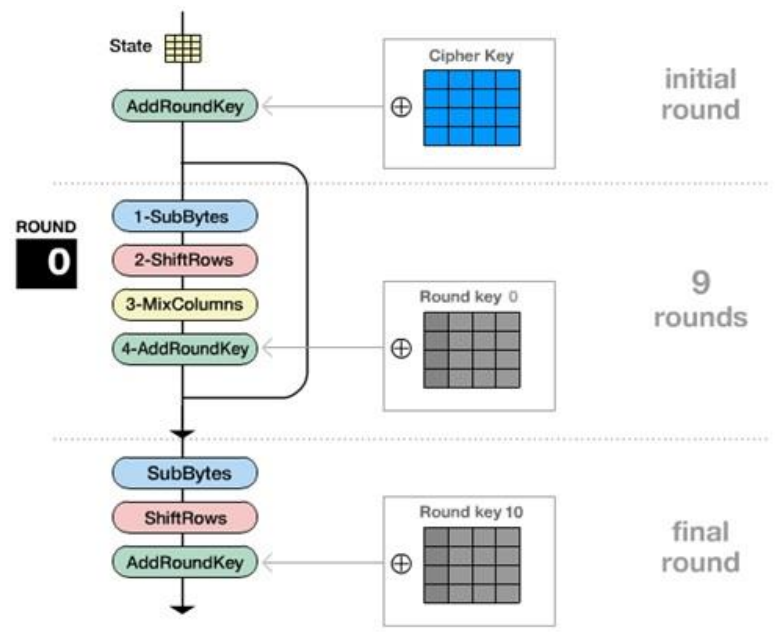

Gambar 2. Proses enkripsi dengan menggunakan algoritma AES-128.

\section{Metode Penelitian}

\subsection{Deskripsi Singkat Aplikasi}

Pada penelitian ini akan dibuat suatu aplikasi enkripsi dekripsi file dokumen dengan menggunakan algoritma AES-128 berbasiskan desktop application.

Aplikasi ini mempunyai dua tujuan yang pertama adalah untuk melakukan proses enkripsi file dokumen yang mempunyai ekstensi .pdf, .doc dan .txt dengan menggunakan symmetric key yang di-inputkan ketika akan dimulai proses enkripsi dengan keluaran hasil yaitu file enkripsi dengan ukuran file yang lebih kecil dan juga waktu proses yang dibutuhkan untuk proses enkripsi.

Tujuan kedua dari aplikasi ini adalah untuk melakukan proses dekripsi terhadap file dokumen yang telah di proses enkripsi sebelumnya. Pada proses ini juga diperlukan key yang sama dengan key yang diinput-kan pada proses enkripsi. Hasil keluaran dari proses dekripsi ini adalah ukuran file yang kembali seperti semula dan waktu proses yang dibutuhkan untuk proses dekripsi.

\subsection{Perancangan Sistem}

Pada perancangan sistem yang akan diterapkan pada penelitian ini akan dijelaskan melalui activity diagram. Dari diagram tersebut permodelan interaksi dari keseluruhan alur kerja sistem dapat digambarkan dengan baik.

Proses pertama adalah proses enkripsi yang dimulai dengan memilih lokasi file yang akan di enkripsi, setelah itu dilanjutkan dengan memasukkan dan mengkonfirmasi kunci enkripsi untuk kemudian dilakukan proses enkripsi yang akan menghasilkan file hasil enkripsi dan informasi mengenai waktu beserta besar ukuran file hasil tersebut.

Proses kedua adalah dekripsi, pada proses ini file yang sebelumnya sudah melalui proses enkripsi dimasukkan lagi sebagai file input-an yang kemudian ditambahkan dengan kunci yang sama, hal ini diperlukan karena peran kunci adalah validasi untuk dapat melanjutkan proses dekripsi. Output dari proses ini adalah file dokumen yang telah terdekripsi beserta waktu dan besar ukuran file dekripsi. 
Dari kedua proses tersebut, dapat dijelaskan pada Gambar 3 dan dalam bentuk activity diagram sebagai berikut:

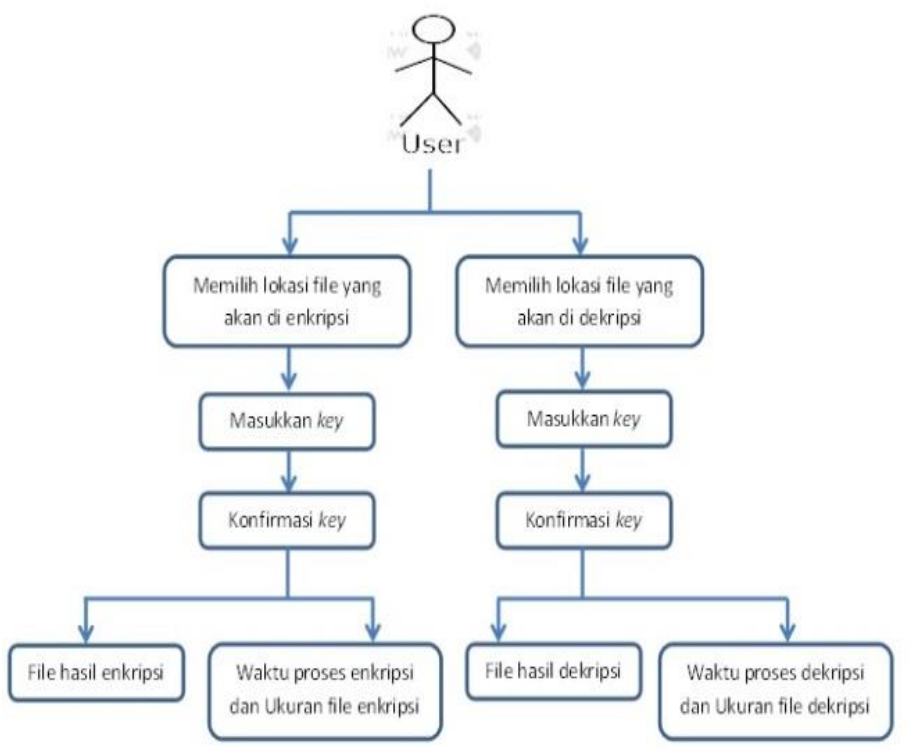

Gambar 3. Activity diagram aplikasi.

\section{Implementasi}

Implementasi merupakan bagian yang menjelaskan tentang pembuatan tampilan aplikasi. Penjelasan mengenai implementasi sebagai berikut.

\subsection{Implementasi Tampilan Menu Utama}

Pada proses awal berjalannya aplikasi, aplikasi akan menampilkan menu utama yang menunjukkan berbagai menu yang ada. Sebagai input-an file dokumen yang akan di enkripsi adalah file dokumen yang berjenis .pdf, .doc, dan .txt.

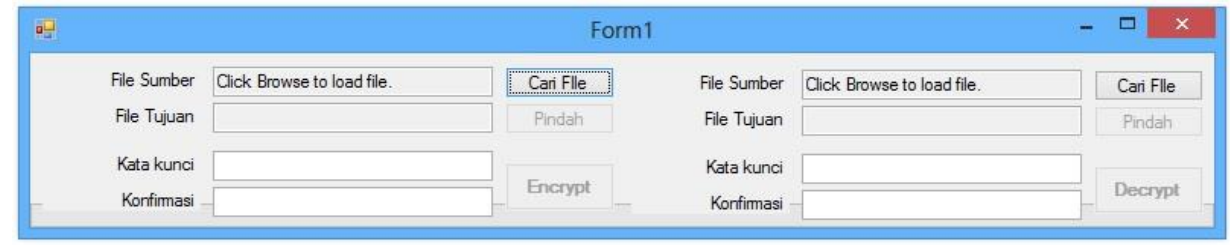

Gambar 4. Tampilan awal aplikasi.

Pada Gambar 4 di atas menunjukkan tentang tampilan awal dan garis besar dari aplikasi ini. Terdapat menu file sumber yakni asal lokasi file yang akan di enkripsi, masukkan kata kunci yang akan dijadikan key, kata kunci ini gabungan dari huruf dan angka dan konfirmasi kata kunci untuk mengulang kata kunci yang sama (symmetric key).

\subsection{Implementasi Tampilan Input Enkripsi File}

Pada proses ini pengguna memilih file yang akan dienkripsi dan memasukkan encryption key. Pada Gambar 5 dijelaskan mengenai file dokumen yang akan dienkripsi disertai dengan memasukkan key dan konfirmasi key. 


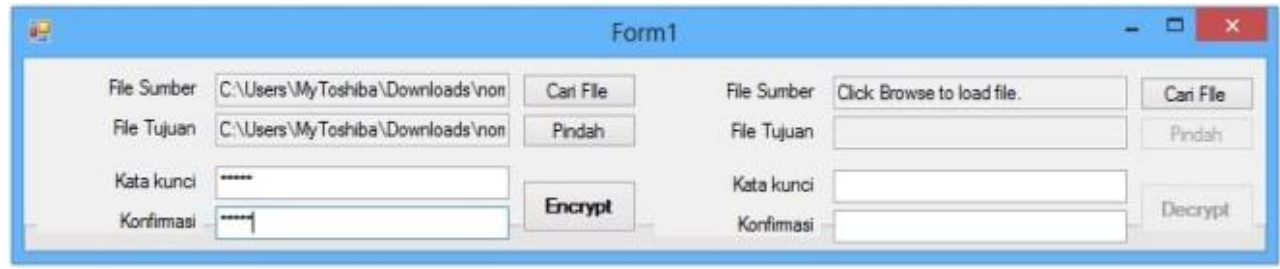

Gambar 5. Tampilan enkripsi input, enkripsi file, dan kata kunci.

\subsection{Implementasi Tampilan File Enkripsi, Waktu yang dibutuhkan dan Ukuran File}

Hasil keluaran dari program ini adalah menampilkan ukuran file yang telah di enkripsi, waktu lama enkripsi dan file yang telah dienkripsi.
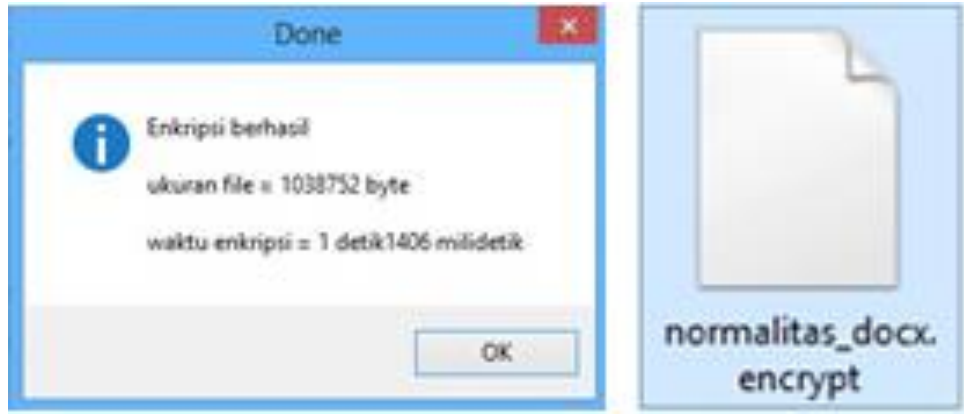

Gambar 6. Tampilan file hasil enkripsi, waktu dan ukuran file.

Pada Gambar 6 di atas menunjukkan tentang informasi yang didapat oleh pengguna sebagai penjelasan akhir dari proses enkripsi. Setelah melakukan proses enkripsi akan keluar pesan berhasil dengan keterangan ukuran file dan waktu yang dibutuhkan. File hasil enkripsi terdapat pada folder yang sama dengan file awal. Hasil file enkripsi ditandai dengan ditambahkannya ekstensi .encrypt untuk hasil keluaran file.

\subsection{Implementasi Tampilan Proses Dekripsi}

Pada proses ini pengguna memilih file yang akan didekripsi dan decryption key.

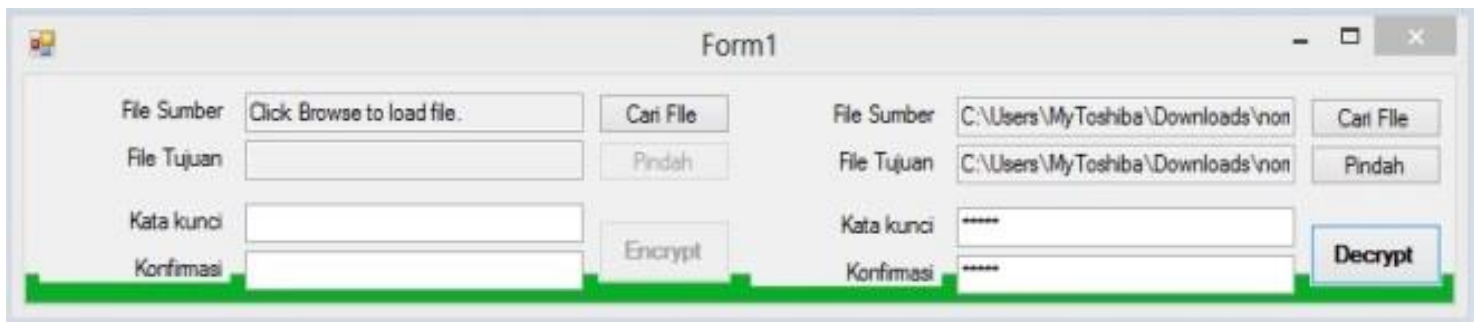

Gambar 7. Tampilan dari proses dekripsi.

Pada proses dekripsi dimulai dengan memasukkan file hasil enkripsi dan decryption key yang sesuai dengan proses enkripsi awal.

\subsection{Implementasi Tampilan Hasil Dekripsi}

Pada proses ini akan ditampilkan hasil dekripsi dimana hasil dari proses dekripsi adalah file awal yang sama sebelum diproses. Di samping hasil file, juga tercantum informasi ukuran file hasil dekripsi dan waktu yang dibutuhkan untuk dekripsi. 


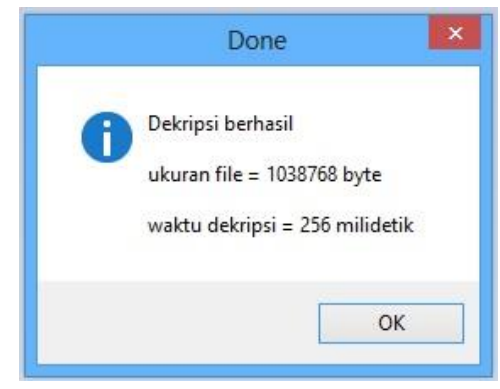

Gambar 8. Tampilan hasil dekripsi.

\section{Uji Coba}

Fase uji coba terhadap aplikasi ini dilakukan pada beberapa file dokumen yang terdiri dari 2 file dokumen berjenis . $d o c, 2$ file dokumen berjenis .txt dan 2 file dokumen berjenis .pdf dengan besar ukuran file berbeda-beda.

Dari file-file di atas dapat dijabarkan proses enkripsi dalam bentuk tabel seperti di bawah ini:

Tabel 2. Tabel uji coba enkripsi.

\begin{tabular}{lllll}
\hline No & Nama File & Ukuran File awal & Ukuran File enkripsi & Waktu enkripsi \\
\hline 1. & Example 1.pdf $(12 \mathrm{Hal})$ & 7178000 byte & 7349271 btye & $3,389 \mathrm{dtk}$ \\
\hline 2. & Example 2.pdf $(16 \mathrm{Hal})$ & 818000 byte & 836961 byte & $0,156 \mathrm{dtk}$ \\
\hline 3. & Example 3.docx $(17 \mathrm{Hal})$ & 1015000 byte & 1038752 byte & $0,312 \mathrm{dtk}$ \\
\hline 4. & Example $4 . d o c(17 \mathrm{Hal})$ & 133000 byte & 136192 byte & $0,156 \mathrm{dtk}$ \\
\hline 5. & Example 5.txt & 3000 byte & 2990 byte & 0 dtk \\
\hline 6. & Example $6 . t x t$ & 8000 byte & 8062 byte & 0 dtk \\
\hline
\end{tabular}

Dari tabel di atas dapat dilihat untuk ukuran file awal dalam bentuk byte. Untuk tiap contoh yang digunakan juga dicantumkan banyaknya halaman sebagai referensi ukuran file awal, dari parameterparameter tersebut dapat di hitung berapa hasil ukuran file enkripsi dan waktu enkripsi yang dibutuhkan untuk masing-masing contoh.

Dari tabel hasil enkripsi di atas, proses kemudian dilanjutkan dengan proses dekripsi yang kemudian hasilnya dapat dilihat pada tabel di bawah ini:

Tabel 3. Tabel uji coba dekripsi.

\begin{tabular}{lllll}
\hline No & Nama File & Ukuran File enkripsi & Ukuran File dekripsi & Waktu dekripsi \\
\hline 1. & Example 1_pdf.encrypt & 7349271 btye & 7349280 byte & $2,558 \mathrm{dtk}$ \\
\hline 2. & Example 2_pdf.encrypt & 836961 byte & 836976 byte & $0,312 \mathrm{dtk}$ \\
\hline 3. & Example 3_docx.encrypt & 1038752 byte & 1038768 byte & $0,312 \mathrm{dtk}$ \\
\hline 4. & Example 4_doc.encrypt & 136192 byte & 136208 byte & $0,06 \mathrm{dtk}$ \\
\hline 5. & Example 5_txt.encrypt & 2990 byte & 2992 byte & $0,01 \mathrm{dtk}$ \\
\hline 6. & Example 6_txt.encrypt & 8062 byte & 8064 byte & $0,156 \mathrm{dtk}$ \\
\hline
\end{tabular}

Dari tabel hasil dekripsi di atas dapat dilihat ukuran file enkripsi yang lebih kecil dari file awal dan kemudian di dekripsi menjadi ukuran file semula, waktu yang dibutuhkan tergantung dari masing-masing file yang akan didekripsi. Beberapa file membutuhkan waktu yang relatif lebih singkat dari proses enkripsi, ada beberapa yang membutuhkan tambahan waktu lebih lama sepersekian detik.

\section{Kesimpulan}

Dari hasil uji coba enkripsi dan dekripsi di atas dapat disimpulkan bahwa:

1. Algoritma AES-128 dapat dijadikan salah satu alternatif untuk proses keamanan data dalam hal ini enkripsi dan dekripsi file dokumen.

2. Ukuran file merupakan salah satu variabel yang cukup penting karena berpengaruh terhadap waktu proses enkripsi dan dekripsi. Pada variabel hasil, waktu merupakan tolak ukur dari proses, apakah terhitung cepat atau lambat dari ukuran file yang harus diproses.

3. Hasil dari enkripsi ini bisa dijamin keamanannya selama symmetry key encryption tidak bocor ke pihak yang tidak bertanggung jawab. 
4. Dari hasil penelitian telah dibuktikan bahwa isi file awal yang mengalami proses enkripsi, kemudian mengalami proses dekripsi, maka akan kembali seperti file awal semula.

5. Dari hasil enkripsi dan dekripsi file, pada penelitian bisa disimpulkan bahwa waktu yang dibutuhkan relatif lebih cepat dibanding dengan penelitian sebelumnya (Yulius Rio, 2016) . Proses enkripsi untuk 7,1 MB dibutuhkan waktu 3,3 detik, dibandingkan dengan 1,8 MB dibutuhkan waktu 1 detik. Proses dekripsi untuk 7,2 MB dibutuhkan waktu 2.5 detik dibandingkan dengan 1,8 MB dibutuhkan waktu 0.4 detik.

\section{Daftar Pustaka}

[1] Soni Harza Putra, dkk., "Implementasi Algoritma Kriptografi ADVANCED ENCRYPTION STANDARD (AES) Pada Kompresi Data Teks”. Jurnal Teknologi Informasi, Universitas Brawijaya Malang. 2013.

[2] Voni Yuniati, dkk. "Enkripsi dan Dekripsi Dengan Algoritma AES-256 Untuk Semua Jenis File". Jurnal nformatika Volume 5 No. 1 April 2009.

[3] Veronica Lusiana. "Implementasi Kriptografi Pada File Dokumen Menggunakan Algoritma AES$128 " .2013$.

[4] Rifkie Primartha. "Penerapan Enkripsi dan Dekripsi File Menggunakan Algoritma Advanced Encryption Standard (AES)". Journal Research in Computer Science and Applications Vol.2 No.1 Januari 2013 ISSN: 2301-8488. 2013.

[5] Yulius Rio Pujianto, dkk. "Perancangan dan Impelementasi Aplikasi Kriptografi Algoritma AES-128 Pada File Dokumen”.Artikel Ilmiah Program Studi Teknik Informartika, Fakultas Teknologi Informasi, Universitas Kristen Satya Wacana, Salatiga. 2016.

[6] Munir, Rinaldi. Kriptografi. Bandung:Penerbit Informatika. 2006.

[7] R.Kristoforus JB, dkk. "Implementasi Algoritma Rijndael Untuk Enkripsi dan Dekripsi Pada Citra Digital”.Seminar Nasional Aplikasi Teknologi Informasi 2012 (SNATI 2012). ISSN: 1907-5022. 2012. 